\title{
Cost-effectiveness of candesartan versus losartan in the primary preventive treatment of hypertension
}

This article was published in the following Dove Press journal:

ClinicoEconomics and Outcomes Research

31 October 2012

Number of times this article has been viewed

\author{
Ola Granström' \\ Lars-Åke Levin ${ }^{2}$ \\ Martin Henriksson' \\ 'AstraZeneca Nordic, Södertälje, \\ ${ }^{2}$ Center for Medical Technology \\ Assessment, Linköping University, \\ Linköping, Sweden
}

Correspondence: Martin Henriksson AstraZeneca Nordic, Astraallén, B674, Södertälje I5I85, Sweden Tel +4676779 7723

Email martin.x.henriksson@astrazeneca. com
Background: Although angiotensin receptor blockers have different receptor binding properties, no comparative randomized studies with cardiovascular event endpoints have been performed for this class of drugs. The aim of this study was to assess the long-term cost-effectiveness of candesartan $\left(\right.$ Atacand $^{\circledR}$ ) versus generic losartan in the primary preventive treatment of hypertension.

Methods: A decision-analytic model was developed to estimate costs and health outcomes over a patient's lifetime. Data from a clinical registry study were used to estimate event rates for cardiovascular complications, such as myocardial infarction and heart failure. Costs and quality of life data were from published sources. Costs were in Swedish kronor and the outcome was quality-adjusted life-years (QALYs).

Results: Due to reduced rates of cardiovascular complications, candesartan was associated with a QALY gain and lower health care costs compared with generic losartan (0.053 QALYs gained and reduced costs of approximately 4700 Swedish kronor for women; and 0.057 QALYs gained and reduced costs of approximately 4250 Swedish kronor for men). This result was robust in several sensitivity analyses.

Conclusion: When modeling costs and health outcomes based on event rates for cardiovascular complications from a real-world registry study, candesartan appears to bring a QALY gain and a reduction in costs compared with generic losartan in the primary preventive treatment of hypertension in Sweden.

Keywords: hypertension, angiotensin receptor blockers, cost-effectiveness, decision analysis

\section{Introduction}

Hypertension is an important risk factor for the development of cardiovascular disease, and blood pressure-lowering treatments have preventive effects. ${ }^{1}$ The renin-angiotensin-aldosterone system is targeted by some of the most widely used antihypertensive medication classes, ie, angiotensin-converting enzyme inhibitors and angiotensin receptor blockers (ARBs). ARBs are being used increasingly in the preventive treatment of hypertension because they have fewer side effects than the angiotensin-converting enzyme inhibitors, combined with similar blood pressurelowering and cardiovascular disease risk reduction abilities. ${ }^{2,3}$

Candesartan (patent-protected as Atacand ${ }^{\circledR}$ ) and losartan are the most widely used ARBs in Sweden, accounting for most ARB prescriptions. Candesartan and losartan belong to the same class of drugs, but have important pharmacological differences, and it has been shown that binding to the AT1 receptor is tighter and lasts longer with candesartan than with losartan. ${ }^{4-6}$ 
No head-to-head, randomized comparative studies have been performed comparing candesartan with losartan. In the absence of randomized evidence, a recent study compared treatment with candesartan versus losartan in clinical practice with respect to cardiovascular events and hospitalizations in hypertensive patients. ${ }^{7,8}$ That study demonstrated that candesartan lowers the risk of cardiovascular events compared with losartan (hazards ratio $0.86,95 \%$ confidence interval $0.77-0.96, P=0.0062) .^{7}$ The clinical conclusions did not change in different model specifications controlling for various confounders across subgroups or in a propensity scorematched analysis. ${ }^{79}$ It was also shown that treatment with losartan was associated with a higher cost than treatment with candesartan over an 8-year period. ${ }^{8}$ Furthermore, a recent register study found candesartan to be associated with lower overall mortality compared with losartan in heart failure. ${ }^{10}$

Although not randomized, these data provide important information for health care decision-makers. However, in order to allocate scarce health care resources between treatment strategies, long-term costs and health effects need to be explicitly compared in a cost-effectiveness analysis. Therefore, this study compares the cost-effectiveness of candesartan and generic losartan in Swedish adults with hypertension.

\section{Materials and methods Overview of cost-effectiveness analysis}

The treatment strategies under evaluation in the current analysis are defined as primary preventive treatment of hypertension with either candesartan or losartan. The duration of treatment is varied in different scenarios, with a 4-year duration being applied in the base-case analysis. The analysis was undertaken from a Swedish health care perspective and costs are expressed in Swedish kronor at 2011 prices. Health outcomes were estimated in terms of life expectancy and quality-adjusted life-years (QALYs). Costs and health outcomes were discounted by $3 \%$ per annum. ${ }^{11}$

A decision-analytic model was used to estimate lifetime costs and health outcomes with respective treatment strategies. The model has a Markov structure and is shown in Figure 1. In a Markov structure, hypothetical individuals reside in one of a set of mutually exclusive health states at each and every point in time. ${ }^{12}$ During periods of equal length (Markov cycles), individuals can make a transition from one health state to another, with transitions between health states being determined by transition probabilities. Each health state is associated with a cost and a health outcome. Costs and health outcomes from each Markov cycle are accumulated and summarized for the

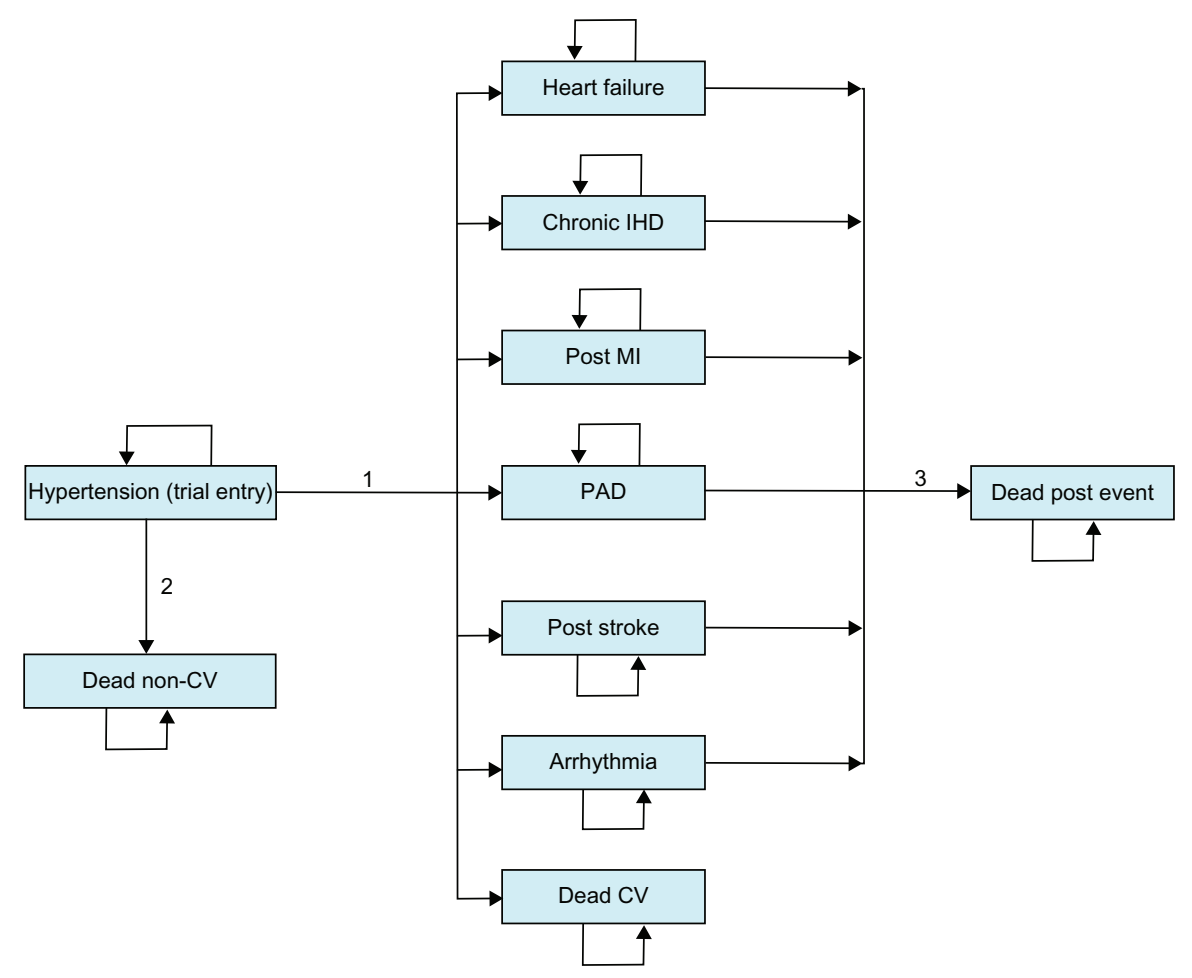

Figure I Model structure.

Notes: Transition I is a summary term for the risks of seven different events. Transition 2 is the risk of noncardiovascular death and transition 3 is the mortality risk after a nonfatal event has occurred.

Abbreviations: IHD, ischemic heart disease; MI, myocardial infarction; PAD, peripheral arterial disease; CV, cardiovascular. 
cohort at the termination of the analysis. Half-cycle correction was applied in the analysis of the model.

Health states in the Markov model are based on cardiovascular events measured in the previously reported registry study, ie, heart failure, chronic ischemic heart disease, post myocardial infarction, peripheral arterial disease, post stroke, arrhythmia, and death from cardiovascular causes. ${ }^{7}$ Patients start in the hypertension state, which represents the status of patients when entering the registry study. The key transitions in the model are the risks of the different cardiovascular events (summarized as transition 1 in Figure 1). Annual Markov cycles were applied in the model, and thus these risks were implemented as annual probabilities of the different events with candesartan and losartan, respectively.

The prognosis following a composite event was estimated by assigning life expectancy, a cost, and a QALY weight associated with each health state. Mortality rates from noncardiovascular causes, by gender, were estimated using life tables subtracting the cardiovascular death component.

\section{Input data}

Three types of input data were required in order to populate the cost-effectiveness model, ie, clinical effectiveness data, health-related quality of life associated with each health state, and costs associated with each health state as well as the cost of drug treatment.

Risks of cardiovascular events are reported in Table 1 and were based on a study utilizing electronic journal data for 14,000 Swedish patients with hypertension treated in primary care. ${ }^{7}$ The study included all patients treated with candesartan or losartan (including single pills as well as the respective fixed-dose combination of the ARB and hydrochlorothiazide)

Table I Annual probabilities of cardiovascular events

\begin{tabular}{lll}
\hline Endpoint & Losartan & Candesartan \\
\hline Heart failure & 0.0064 & 0.0055 \\
Cardiac arrhythmia & 0.0090 & 0.0078 \\
Peripheral arterial disease & 0.0026 & 0.0023 \\
Chronic ischemic heart disease & 0.0090 & 0.0078 \\
Myocardial infarction & 0.0063 & 0.0054 \\
Stroke & 0.0073 & 0.0063 \\
Cardiovascular mortality & 0.0034 & 0.0029 \\
\hline
\end{tabular}

Notes: Probabilities were derived as follows: an annual rate of 0.045 (Kjeldsen et $\left.\mathrm{al}^{7}\right)$ with a gamma distribution, gamma $(100,0.0005)$, defines the risk of a composite endpoint in the losartan group. A hazards ratio of 0.86 (Kjeldsen et $\mathrm{al}^{7}$ ) with a log normal distribution (mean $-0.15 \mathrm{I}$, standard error 0.056 ) was applied to the losartan risk to define the risk of a composite endpoint in the candesartan group. A conditional probability was applied determining whether the composite endpoint was heart failure, cardiac arrhythmia, peripheral arterial disease, chronic ischemic heart disease, myocardial infarction, stroke, or cardiovascular mortality using a Dirichlet distribution $(365,373,108,374,261,303,141)$.

for hypertension in 72 primary care centers. Centers were selected for inclusion to ensure a representative sample of Swedish primary care centers (eg, public and private providers, rural and urban areas, and small, medium, and large-sized centers). ${ }^{7}$ A patient's risk of dying from a noncardiovascular cause (transition 2 in Figure 1) was estimated by reducing the overall mortality risk from standard life tables in Sweden ${ }^{13}$ by the proportion of total deaths that were cardiovascular. Data from the cause of death register were used to estimate the proportion of total deaths that were cardiovascular. ${ }^{14}$

For the survival prognosis after a clinical event, an increased mortality risk above noncardiovascular mortality was applied. This increased risk was higher in the first year after an event and then decreased somewhat during the second and subsequent years after an event (Table 2). Hazard ratios were applied to the noncardiovascular death rates in order to estimate mortality rates following events.

Age-dependent annual baseline QALY estimates (applied in the hypertension state of the model) were based on a Swedish study ${ }^{15}$ and are found in the Appendix. Annual QALY decrements were subtracted from the baseline QALY estimates to derive annual QALY estimates for health states following a cardiovascular event (Table 3).

Table 2 Hazards ratios of increased risk over noncardiovascular death

\begin{tabular}{|c|c|c|}
\hline Parameter & $\begin{array}{l}\text { Hazards } \\
\text { ratio }\end{array}$ & Uncertainty estimate* \\
\hline $\begin{array}{l}\text { First year after a myocardial } \\
\text { infarction }\end{array}$ & 2.50 & Log normal $(0.92,0.15)$ \\
\hline $\begin{array}{l}\text { Second and subsequent years } \\
\text { after a myocardial infarction }\end{array}$ & 2.15 & \\
\hline $\begin{array}{l}\text { First year after ischemic } \\
\text { heart disease }\end{array}$ & 2.50 & Log normal $(0.92,0.15)$ \\
\hline $\begin{array}{l}\text { Second and subsequent years } \\
\text { after ischemic heart disease }\end{array}$ & 2.15 & \\
\hline First year after heart failure & 2.50 & Log normal $(0.92,0.15)$ \\
\hline $\begin{array}{l}\text { Second and subsequent years } \\
\text { after heart failure }\end{array}$ & 2.15 & \\
\hline First year after arrhythmia & 2.50 & Log normal $(0.92,0.15)$ \\
\hline $\begin{array}{l}\text { Second and subsequent years } \\
\text { after arrhythmia }\end{array}$ & 2.15 & \\
\hline First year after stroke & 3.50 & Log normal $(1.25,0.15)$ \\
\hline $\begin{array}{l}\text { Second and subsequent years } \\
\text { after stroke }\end{array}$ & 2.98 & \\
\hline $\begin{array}{l}\text { First year after peripheral } \\
\text { arterial disease }\end{array}$ & 2.50 & Log normal $(0.92,0.15)$ \\
\hline $\begin{array}{l}\text { Second and subsequent years } \\
\text { after peripheral arterial disease }\end{array}$ & 2.15 & \\
\hline
\end{tabular}


Table 3 QALY decrements and costs for cardiovascular events

\begin{tabular}{|c|c|c|c|}
\hline Health state & QALY decrement & Distribution & Reference \\
\hline Heart failure & 0.070 & Gamma $(1.96,0.04)$ & Alehagen et a $\left.\right|^{17}$ \\
\hline Cardiac arrhythmia & 0.065 & Gamma $(42,0.002)$ & Reynolds et al ${ }^{18}$ \\
\hline Peripheral arterial disease & 0.250 & Gamma $(6,0.04)$ & Sigvant et al ${ }^{16}$ \\
\hline Chronic ischemic heart disease & 0.090 & Gamma $(3,0.03)$ & Clarke et al ${ }^{19}$ \\
\hline Myocardial infarction & 0.055 & Gamma $(30,0.002)$ & Clarke et al ${ }^{19}$ \\
\hline Stroke & 0.145 & Gamma $(3,0.06)$ & Lindgren et $\mathrm{a}^{120}$ \\
\hline Health state & Cost (mean) & Distribution & Reference \\
\hline Heart failure & & & Agvall et $\mathrm{al}^{21}$ \\
\hline Year I & 41,769 & Gamma $(17,2394)$ & \\
\hline Year 2+ & 41,769 & NA & \\
\hline Cardiac arrhythmia & & & Davidsson and Levin ${ }^{22}$ \\
\hline Year I & 4023 & Gamma (4994) & \\
\hline Year 2+ & 4023 & NA & \\
\hline Peripheral arterial disease & & & Sigvant et al ${ }^{16}$ \\
\hline Year I & 193,660 & Gamma $(60,3227)$ & \\
\hline Year 2+ & 57,873 & Gamma $(68,847)$ & \\
\hline Chronic ischemic heart disease & & & Henriksson et $\mathrm{al}^{23}$ \\
\hline Year I & 6824 & Gamma $(2,3664)$ & \\
\hline Year 2+ & 6824 & NA & \\
\hline Myocardial infarction & & & Sigvant et al ${ }^{16}$ \\
\hline Year I & 155,194 & Gamma $(60,2577)$ & \\
\hline Year 2+ & 41,356 & Gamma $(68,605)$ & \\
\hline Stroke & & & Ghatnekar et $\mathrm{a}^{24}$ \\
\hline Year I & 169,984 & Gamma $(72,2353)$ & \\
\hline Year 2+ & 59,684 & Gamma $(73,82 I)$ & \\
\hline
\end{tabular}

Notes: 201 I Swedish kronor values used (inflated using consumer price index from Statistics Sweden if needed). Original cost estimates may be in other currencies and were converted to Swedish kronor.

Abbreviation: NA, Not available.

Each health state in the model is associated with a cost in the year it occurs as well as a maintenance cost in subsequent years. These costs are presented in Table 3. Each treatment strategy is associated with an annual drug cost. The cost of losartan was 234 Swedish kronor for every year in the model. The annual candesartan cost was 2435 Swedish kronor during the first year in the model. Thereafter, the annual drug cost for losartan was applied also in the candesartan strategy, assuming that generic candesartan would have the same price as generic losartan (see Appendix for details).

\section{Analysis}

The model was analyzed using probabilistic sensitivity analysis, whereby inputs into the analysis are defined as probability distributions which reflect the precision with which they are estimated. ${ }^{12}$ In each simulation in the probabilistic analysis, parameter values were drawn randomly from the defined probability distributions, and a cohort of hypothetical individuals was run through the model, and mean costs and health outcomes were calculated for both strategies. This procedure was repeated 5000 times. The expected costs and health outcomes for each treatment strategy are the mean of these 5000 simulations.
The probability of candesartan being cost-effective at different levels of willingness to pay for a QALY (or QALY threshold values) was also assessed. In addition, several scenario analyses were undertaken in order to assess the robustness of the assumptions made in the base-case analyses and to explore the validity of the model.

The age of the patients in the base-case analysis is 62 years (the mean age in the registry study generating the effectiveness $\operatorname{data}^{7}$ ) and the analysis takes a lifetime perspective, indicating that the model is analyzed until all patients have died. Both starting age and time perspective is varied in the subgroup and sensitivity analyses.

\section{Results}

As a consequence of reduced rates of cardiovascular complications, candesartan is associated with a gain in QALYs and lower health care costs compared with generic losartan $(0.053$ QALYs gained and a reduction in costs of approximately 4700 Swedish kronor for women, and 0.057 QALYs gained and a reduction in costs of approximately 4250 Swedish kronor for men). The detailed cost analysis showed that stroke and chronic heart failure contributed substantially to the estimated cost differences between candesartan and losartan (Table 4). The results of the probabilistic sensitivity analysis for men 
Table 4 Detailed cost (Swedish kronor) and cost-effectiveness results of base-case analysis for women and men

\begin{tabular}{|c|c|c|c|c|c|c|}
\hline \multirow[t]{2}{*}{ Cost item } & \multicolumn{3}{|l|}{ Men } & \multicolumn{3}{|l|}{ Women } \\
\hline & Candesartan & Losartan & Difference & Candesartan & Losartan & Difference \\
\hline Drug cost & $183 \mid$ & 723 & 1108 & 1833 & 725 & 1108 \\
\hline Stroke-related & $53,8 \mid 4$ & 55,407 & -1593 & 63,737 & 65,455 & -1718 \\
\hline Ml-related & 33,636 & 34,852 & -1216 & 38,963 & 40,267 & -1304 \\
\hline CHD-related & 6243 & 6489 & -246 & 7260 & 7525 & -265 \\
\hline Heart failure-related & 37,779 & 39,273 & -1494 & 44,843 & 46,474 & $-163 \mid$ \\
\hline Arrhythmia related & $366 I$ & 3806 & -145 & 4321 & 4478 & -157 \\
\hline PAD-related & 19,202 & 19,876 & -674 & 22,275 & 23,000 & -725 \\
\hline Total costs & 156,166 & 160,425 & -4259 & 183,233 & 187,925 & -4692 \\
\hline Life years & 14.307 & 14.253 & 0.054 & 15.606 & 15.556 & 0.050 \\
\hline QALYs & II.138 & | I.08| & 0.057 & 11.218 & 11.165 & 0.053 \\
\hline Cost per life-year gained & \multicolumn{3}{|l|}{ Dominant* } & \multicolumn{3}{|l|}{ Dominant* } \\
\hline Cost per QALY gained & \multicolumn{3}{|l|}{ Dominant* } & \multicolumn{3}{|l|}{ Dominant* } \\
\hline
\end{tabular}

Note: *Candesartan is associated with a gain in life years/QALYs and lower costs compared with losartan.

Abbreviations: CHD, coronary heart disease; PAD, peripheral arterial disease; MI, myocardial infarction; QALY, quality-adjusted life-years.

are shown in Figure 2 (the results for women are very similar and have been excluded here). The probability of candesartan being cost-effective is close to $100 \%$ at all levels of willingness to pay per QALY.

\section{Sensitivity and subgroup analysis}

The results appear not to be sensitive when varying some key parameters in a one-way sensitivity analysis (Table 5). Furthermore, analyzing different age groups did not have an impact on the conclusion regarding cost-effectiveness. Finally, candesartan treatment is associated with a gain in QALYs regardless of the treatment duration applied in the analysis, although the magnitude of this gain varies considerably with treatment duration (Figure 3). Similar results are seen for costs (Figure 3). Therefore, candesartan is a dominant strategy (ie, producing QALY gains at a lower cost) regardless of treatment duration.

\section{Discussion}

The present cost-effectiveness analysis of candesartan versus generic losartan in the primary preventive treatment of hypertension in Swedish clinical practice shows

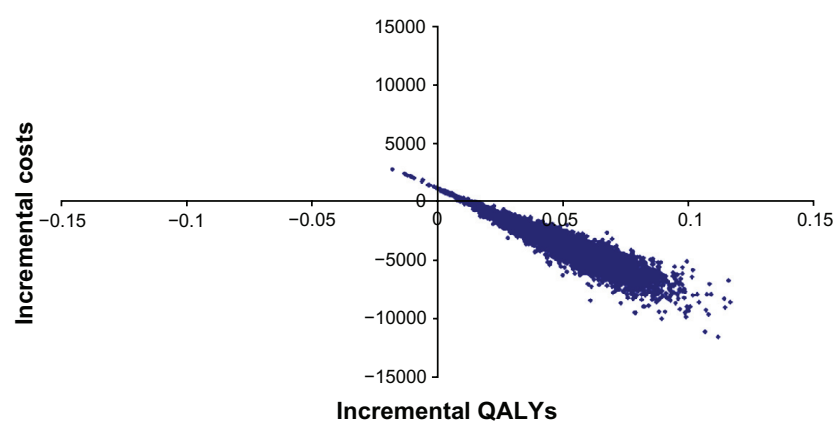

Figure 2 Results on the cost-effectiveness plane comparing candesartan with losartan. Abbreviation: QALY, quality-adjusted life-years. that candesartan is a dominant treatment strategy, meaning that it is associated with health benefits (ie, a QALY gain) at a reduced cost compared with generic losartan. In the base-case analysis, the QALY gain with candesartan versus losartan is 0.057 for men and 0.053 for women, and the cost savings amount to approximately 4250 and 4700 Swedish kronor for men and women, respectively. This result is consistent when looking at patients of different ages.

The cost-effectiveness results appear robust when investigating different sensitivity scenarios, such as varying the time frame of the analysis or altering certain parameters in one-way sensitivity analyses. The probabilistic sensitivity analysis indicates that the probability of candesartan being cost-effective is very high.

The current study has important strengths. First, the clinical effectiveness data are collected in real-world clinical practice, indicating that the external validity should be high. Second, the analysis is based on conservative estimates of total costs; it does not take into account outpatient visits at the hospital (specialist care), nor does it consider indirect costs (societal productivity loss) due to work absence. Patient age in the base-case analysis is 62 years, ${ }^{7}$ so the indirect costs associated with sick leave due to cardiovascular events are likely to be non-negligible. Third, the cost difference between candesartan and losartan estimated in this pure model approach is similar to the results of the within-trial cost study based on the clinical registry data. ${ }^{8}$

A limitation when using registry data is that observed clinical outcomes may be biased, due to the inability to control fully for confounding factors. However, the registry study on which the clinical outcomes were based went to great lengths in assuring that the clinical results were not due 
Table 5 Results sensitivity scenarios

\begin{tabular}{|c|c|c|c|c|c|c|}
\hline \multirow[t]{2}{*}{ Sensitivity analysis* } & \multicolumn{2}{|c|}{ QALYs gained } & \multicolumn{2}{|c|}{$\begin{array}{l}\text { Discounted total cost } \\
\text { difference (SEK) }\end{array}$} & \multicolumn{2}{|c|}{ Cost/QALY } \\
\hline & Men & Women & Men & Women & Men & Women \\
\hline Base case & 0.057 & 0.053 & -4259 & -4692 & Dominant & Dominant \\
\hline No increased mortality risk post events ${ }^{\mathrm{D}}$ & 0.032 & 0.033 & -5425 & -5845 & Dominant & Dominant \\
\hline Starting age of cohort 70 years & 0.053 & 0.050 & -3155 & -3714 & Dominant & Dominant \\
\hline Starting age of cohort 75 years & 0.049 & 0.048 & -2442 & -2948 & Dominant & Dominant \\
\hline All QALY decrements $30 \%$ higher & 0.061 & 0.058 & -4261 & -4755 & Dominant & Dominant \\
\hline All QALY decrements $30 \%$ lower & 0.052 & 0.047 & -4233 & -4708 & Dominant & Dominant \\
\hline All costs post event $30 \%$ higher & 0.057 & 0.053 & -5858 & -6448 & Dominant & Dominant \\
\hline All costs post event $30 \%$ lower & 0.057 & 0.053 & -2658 & -2933 & Dominant & Dominant \\
\hline
\end{tabular}

Notes: *Everything else as in the base case analysis. "Standard mortality (from life table) applied also for post event states.

Abbreviations: QALY, quality-adjusted life-years; SEK, Swedish kronor.

to confounding factors. The clinical conclusions remained unaltered across various model specifications and when excluding diabetic patients from the analysis. ${ }^{7}$ Moreover, there was no difference in hospitalizations for noncardiovascular reasons prior to study entry between the treatment strategies, further indicating that the treatment groups did not differ substantially when included in the registry study. ${ }^{8}$ Finally, a propensity score-matching analysis of matched can- desartan and losartan patients as well as subgroup analyses did not alter the clinical conclusions. ${ }^{9}$

This study demonstrates that a reduction in cardiovascular events in the primary treatment of hypertensive patients with candesartan rather than losartan will improve quality-adjusted survival and reduce health care costs. It is important to point out that health care costs are reduced despite the higher drug costs of patent-protected candesartan for the first year of the

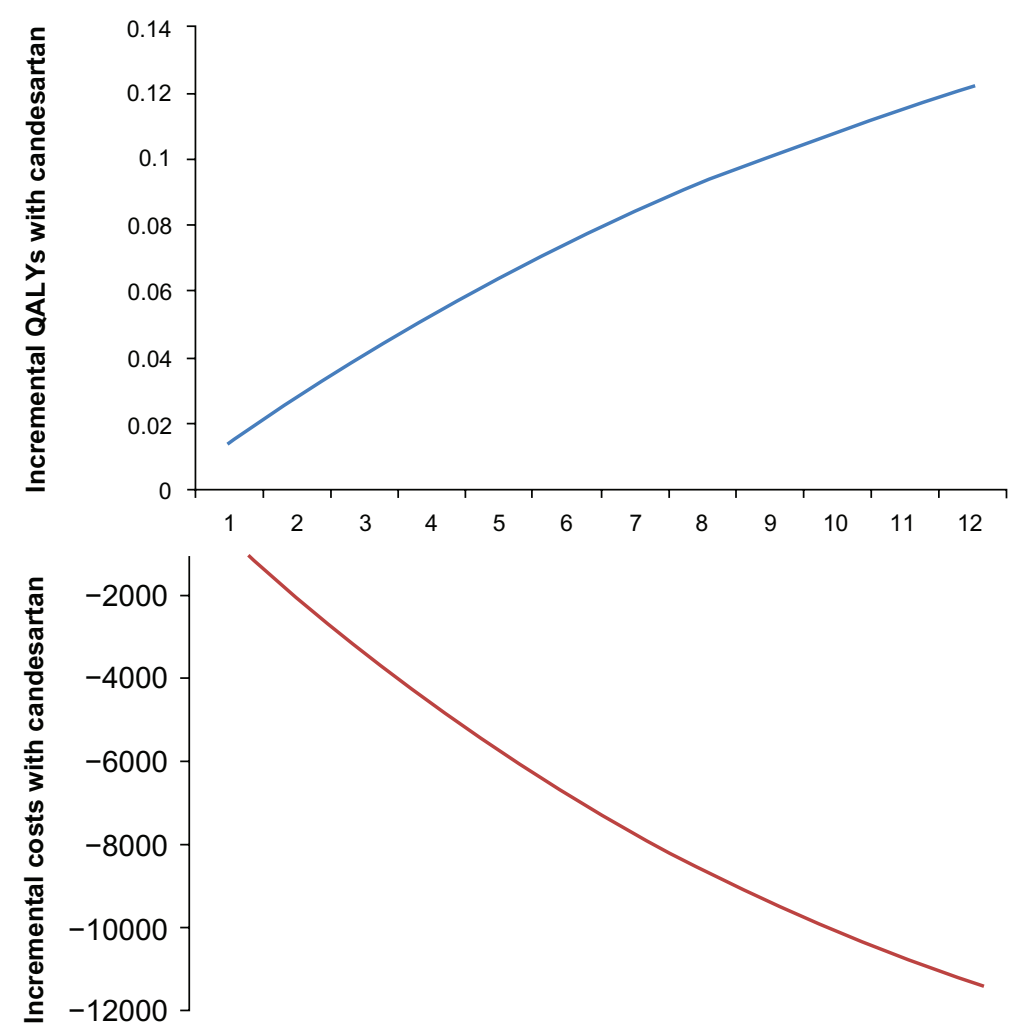

Duration of treatment in years

Figure 3 Incremental costs and QALYs for candesartan compared with losartan by treatment duration. Abbreviation: QALY, quality-adjusted life-years. 
analysis compared with losartan where generic prices are applied throughout. The reason is that the additional drug cost of candesartan is balanced by the high costs associated with more cardiovascular events in the losartan group. When candesartan loses exclusivity, losartan and candesartan are likely to have the same (or very similar) generic prices also in the first year of analysis. The results of the current analysis will thus be further reinforced because the difference in drug costs will be minimal. With generic losartan and candesartan available, health care decision-makers only need to consider differences in clinical effectiveness and the implication of such a difference on health care costs (excluding the cost of the ARBs) and long-term quality-adjusted survival. In this context, the present study estimates that a $14 \%$ reduction in cardiovascular events over 4 years translates into a gain in quality-adjusted survival of approximately 0.055 in a patient population, with the risk profile and treatment pattern corresponding to that observed in the registry study that provided the clinical data for our study, ${ }^{7}$ and a reduction in health care costs of approximately 3000 Swedish kronor. In order for these results to hold in health care settings other than the Swedish one, health care decision-makers primarily need to consider whether the clinical inputs derived from the Swedish registry study apply in their particular setting. Furthermore, the relevance of other inputs, such as costs and QALY estimates, has to be considered in this context, although they should be less crucial than the clinical inputs for generalizability to other settings. Finally, we notice that there may be ARB comparators more relevant to candesartan than losartan in other health care settings.

In conclusion, when modeling costs and health outcomes based on event rates of cardiovascular complications from a Swedish real-world registry study, candesartan appears to bring a QALY gain and a reduction in costs compared with generic losartan in the primary preventive treatment of hypertension in Sweden.

\section{Disclosure}

$\mathrm{MH}$ is an employee of AstraZeneca. OG was an employee of AstraZeneca when the study was conducted, but has since moved to another pharmaceutical company. L-AL has acted as a paid consultant for AstraZeneca on other projects.

\section{References}

1. Lawes CM, Vander Hoorn S, Rodgers A; International Society of Hypertension. Global burden of blood-pressure-related disease, 2001. Lancet. 2008;371:1513-1518.

2. Gavras H. Update on the clinical pharmacology of candesartan cilexetil. Am J Hypertens. 2000;13:25S-30S.
3. Yusuf S, Teo KK, Pogue J, et al. Telmisartan, ramipril, or both in patients at high risk for vascular events. $N$ Engl J Med. 2008;358: $1547-1559$

4. Van Liefde I, Vauquelin G. Sartan-AT1 receptor interactions: in vitro evidence for insurmountable antagonism and inverse agonism. Mol Cell Endocrinol. 2009;302:237-243.

5. Fabiani ME, Dinh DT, Nassis L, Casley DJ, Johnston CI. In vivo inhibition of angiotensin receptors in the rat kidney by candesartan cilexetil: a comparison with losartan. Am J Hypertens. 2000;13: $1005-1013$

6. Ojima M, Inada Y, Shibouta Y, et al. Candesartan (CV-11974) dissociates slowly from the angiotensin AT1 receptor. Eur J Pharmacol. 1997;319:137-146.

7. Kjeldsen SE, Stalhammar J, Hasvold P, Bodegard J, Olsson U, Russell D. Effects of losartan vs candesartan in reducing cardiovascular events in the primary treatment of hypertension. J Hum Hypertens. 2010;24:263-273.

8. Henriksson M, Russell D, Bodegard J, et al. Health-care costs of losartan and candesartan in the primary treatment of hypertension. J Hum Hypertens. 2010;25:130-136.

9. Russell D, Stålhammar J, Bodegard J, Hasvold P, Thuresson M, Kjeldsen SE. Cardiovascular events in subgroups of patients during primary treatment of hypertension with candesartan or losartan. J Clin Hypertens. 2011;13:189-197.

10. Eklind-Cervenka M, Benson L, Dahlstrom U, Edner M, Rosenqvist M, Lund LH. Association of candesartan vs losartan with all-cause mortality in patients with heart failure. JAMA. 2011;305: $175-182$.

11. LFN. Läkemedelsförmånsnämndens allmänna råd om ekonomiska utvärderingar. LFNAR 2003:2. Available from: http://www.tlv.se. Accessed September 20, 2012.

12. Briggs AH, Claxton K, Sculpher MJ. Decision Modelling for Health Economic Evaluation. Oxford, UK: Oxford University Press; 2006.

13. Statistics Sweden. Life table (Livslängdstabell) 2005-2009. Available from: http://www.scb.se. Accessed September 20, 2012.

14. Board of Health and Welfare. Statistics database, cause of death statistics. Available from: http://www.socialstyrelsen.se. Accessed September 20, 2012.

15. Burström K, Rehnberg K. Hälsorelaterad livskvalitet i Stockholms län 2002. Resultat per åldersgrupp och kön, utbildningsnivå, födelseland samt sysselsättningsgrupp - en befolkningsundersökning med EQ-5D. Rapport 2006:1, Centrum för folkhälsa, Enheten förSocialmedicin och Hälsoekonomi, Stockholms läns landsting.

16. Sigvant B, Henriksson M, Lundin F, Wahlberg E. Asymptomatic peripheral arterial disease: is pharmacological prevention of cardiovascular risk cost-effective? Eur J Cardiovasc Prev Rehabil. 2011;18: 254-261.

17. Alehagen U, Rahmqvist M, Paulsson T, Levin LA. Quality-adjusted life year weights among elderly patients with heart failure. Eur J Heart Fail. 2008;10:1033-1039.

18. Reynolds MR, Zimetbaum P, Josephson ME, Ellis E, Danilov T, Cohen DJ. Cost-effectiveness of radiofrequency catheter ablation compared with antiarrhythmic drug therapy for paroxysmal atrial fibrillation. Circ Arrhythm Electrophysiol. 2009;2:362-369.

19. Clarke P, Gray A, Holman R. Estimating utility values for health states of type 2 diabetic patients using the EQ-5D (UKPDS 62). Med Decis Making. 2002;22:340-349.

20. Lindgren P, Kahan T, Poulter N, et al. Utility loss and indirect costs following cardiovascular events in hypertensive patients: the ASCOT health economic substudy. Eur J Health Econ. 2007;8:25-30.

21. Agvall B, Borgquist L, Foldevi M, Dahlstrom U. Cost of heart failure in Swedish primary healthcare. Scand J Prim Health Care. 2005;23: 227-232.

22. Davidsson T, Levin L. Kostnaden för förmaksflimmer i Östergötland. CMT report. Linköping, Sweden: Centre for Medical Technology Assessment, Linköping University; 2006. 
23. Henriksson M, Palmer S, Chen R, et al. Assessing the cost effectiveness of using prognostic biomarkers with decision models: case study in prioritising patients waiting for coronary artery surgery. $B M J$. 2010;340:b5606.
24. Ghatnekar O, Persson U, Glader EL, Terent A. Cost of stroke in Sweden: an incidence estimate. Int J Technol Assess Health Care. 2004;20: 375-380. 


\section{Appendix}

This appendix provides detailed information about some of the input data used in the model, namely utilities, event costs, and drug costs.

\section{Baseline QALY estimates and QALY decrements}

Age-dependent baseline quality-adjusted life-years (QALY) estimates are presented in Table A1. They are based on Burström and Rehnberg who present QALYs based on EQ-5D single-index estimates for different age groups in Sweden. ${ }^{15}$

In terms of uncertainty around the mean QALY estimates (used in the probabilistic sensitivity analysis), a beta distribution was defined for the youngest age group. For older age groups, the proportion of the utility of the youngest age group was applied. QALY decrements for cardiovascular events are found in Table A2. The QALY decrements for heart failure and cardiac arrhythmias merit further explanation.

The QALY decrement for heart failure was estimated as the mean QALY weight across the four heart failure severity levels (classified according to the New York Heart Association). The share of patients in each New York Heart Association class (as assessed by a medical doctor in Alehagen et al) ${ }^{17}$ was used to get the average QALY weight as $0.47 * 0.77+0.39 * 0.68+$ $0.13 * 0.61+0.01 * 0.5=0.7144$. Because the mean age in the study sample reported by Alehagen et al was 72 years, we compared this mean QALY weight with the mean QALY in the general population aged 70-74 years from Burström and Rehnberg, ${ }^{15}$ which was 0.78 . The resulting heart failure QALY decrement was $0.78-0.7114=0.0686$, or approximately 0.07 . This is a more conservative estimate of the QALY decrement in heart failure than the one found in Clarke et al ${ }^{19}$ (namely 0.108). Atrial fibrillation was the most common type of heart arrhythmia in the registry study from which effectiveness data were taken for this cost-effectiveness analysis.

\section{Costs}

\section{Event costs}

The cardiovascular event costs in Table 3 were derived in the following way. Heart failure costs were based on

Table Al Age-dependent baseline QALY estimates based on EQ-5D

\begin{tabular}{llll}
\hline & \multicolumn{3}{l}{ Age group, years } \\
\cline { 2 - 4 } & $\mathbf{5 5 - 6 9}$ & $\mathbf{7 0 - 8 0}$ & $\mathbf{8 0 - 8 4}$ \\
\hline Men & 0.83 & 0.80 & 0.74 \\
Women & 0.78 & 0.74 & 0.69 \\
\hline
\end{tabular}

Abbreviation: QALY, quality-adjusted life-years.
Table A2 QALY decrements for cardiovascular events

\begin{tabular}{|c|c|c|c|}
\hline Event & $\begin{array}{l}\text { QALY } \\
\text { decrement }\end{array}$ & Distribution & Reference \\
\hline Heart failure & 0.07 & Gamma $(1.96,0.04)$ & Alehagen et al ${ }^{17}$ \\
\hline $\begin{array}{l}\text { Cardiac } \\
\text { arrhythmia }\end{array}$ & 0.065 & Gamma $(42,0.002)$ & Reynolds et al $^{18}$ \\
\hline $\begin{array}{l}\text { Peripheral } \\
\text { arterial disease }\end{array}$ & 0.25 & Gamma $(6,0.04)$ & Sigvant et al ${ }^{16}$ \\
\hline $\begin{array}{l}\text { Chronic ischemic } \\
\text { heart disease }\end{array}$ & 0.09 & Gamma $(3,0.03)$ & Clarke et a $\left.\right|^{19}$ \\
\hline $\begin{array}{l}\text { Myocardial } \\
\text { infarction }\end{array}$ & 0.055 & Gamma $(30,0.002)$ & Clarke et al ${ }^{19}$ \\
\hline Stroke & 0.145 & Gamma $(3,0.06)$ & Lindgren et $\mathrm{al}^{20}$ \\
\hline
\end{tabular}

Abbreviation: QALY, quality-adjusted life-years.

Agvall et al, ${ }^{21}$ who estimated annual per patient costs in a study of 115 patients in two health care centers in Linköping in 2000. Costs included primary care, hospitalization, drugs, nursing home care, and examinations. We inflated their costs to 2011 Swedish kronor using the consumer price index from Statistics Sweden, with 2003 as the baseline year.

Yearly atrial fibrillation costs are based on Davidsson and Levin, excluding the costs for stroke. ${ }^{22} \mathrm{~A}$ cost per patient was calculated by taking all atrial fibrillation-related costs (except atrial fibrillation costs related to stroke) for year 2006 in the Swedish county of Östergötland and dividing by the number of patients. The total cost of 21,417,028 Swedish kronor in Östergötland was calculated by adding 2,253,068 Swedish kronor for drugs, 15,242,695 Swedish kronor for monitoring, 1,990,781 Swedish kronor for bleeding, and 1,930,484 Swedish kronor for patient travel. Given that the number of individuals with atrial fibrillation in Östergötland was 5846, the cost was calculated as 21,417,028/5846 Swedish kronor, or approximately 3664 Swedish kronor per patient. That amount was inflated to 2011 Swedish kronor (using the consumer price index with 2006 as base year), producing an annual cost for atrial fibrillation per patient of approximately 4023 Swedish kronor.

Costs for peripheral arterial disease and myocardial infarction are based on Sigvant et al. ${ }^{16}$ Sigvant presents costs in Euro based on the Swedish cost per patient (kostnad per patient, KPP) database for 2009, where patients were followed for 3-4 years. Each event cost in Sigvant was converted to Swedish kronor, using the mean exchange rate in 2005-2009, 9.64 Swedish kronor/Euro and inflated to 2011 prices using the consumer price index.

Ischemic heart disease costs are taken from Henriksson et al (Table 1). ${ }^{23}$ Specifically, the ischemic heart disease cost in our model was based on the annual cost for ischemic 
heart disease without an event. Noninflated pounds sterling 2006-2007 costs were converted to Swedish kronor using the mean 2006-2007 exchange rate of 13.56 Swedish kronor/ pounds sterling. Costs were inflated to 2011 prices using the consumer price index.

Stroke costs were based on Ghatnekar et al (Table 3). ${ }^{24}$ They present costs based on inflated present value costs (using a 3\% discount rate) for stroke patients surviving 4 years. Ghatnekar et al estimate costs for years 1, 2, 3 and $4 .^{24}$ In our model, year 1 costs are equal to their year 1 costs. Year $2+$ costs in our model were calculated as the average of year 2-4 costs in Ghatnekar et al, ie, 49,092 + 52,525 + 47,945)/ $3=49,854$ Swedish kronor. Costs were inflated to 2011 Swedish kronor using the Swedish consumer price index with 2000 as the baseline year.

\section{Drug costs}

Annual drug costs are based on the percentage of patients on each drug dose in Kjeldsen et al. ${ }^{7}$ Drug costs were based on the latest available prices for Atacand ${ }^{\circledR}$ (candesartan, the AstraZeneca manufactured version) and generic losartan. All drug prices were taken from the website of the Swedish Dental and Pharmaceutical Benefits Agency (TLV). The price per pill was calculated as the lowest pharmacy selling price per pill, irrespective of pack size and, for losartan, manufacturer. To make sure that the generic losartan version was actually available and sold in pharmacies, the manufactured version of losartan that was selected by the TLV for supply in November 2011 was used for each dose.

The lowest price per pill (per dose) for the version of losartan that was the selected "product of the month" was found in the TLV list for November (updated on November 10, 2011). The following prices per pill for losartan were used: 0.59 Swedish kronor for pill for $50 \mathrm{mg}$ losartan (98-pill pack) by KRKA Sverige; 0.67 Swedish kronor per pill for $100 \mathrm{mg}$ losartan (98-pill pack) by STADAPharm; 0.65 Swedish kronor per pill for $50 \mathrm{mg} / 12.5 \mathrm{mg}$ losartan/hydrochlorothiazide (98-pill pack) by KRKA Sverige; and 0.77 Swedish kronor per pill for $100 \mathrm{mg} / 25 \mathrm{mg}$ losartan/hydrochlorothiazide (98-pill pack) by Bluefish Pharmaceuticals.

Table A3 contains all relevant information from which the average annual candesartan and losartan drug costs were calculated. The average annual losartan cost was calculated as Swedish kronor $0.45 * 215.35+0.05 * 244.55+0.35 * 237$ $0.25+0.15 * 281.05 \approx$ Swedish kronor 234 ; the mean annual candesartan cost as Swedish kronor $0.15 * 5.9+0.35 * 6.38+$ $0.25 * 7.1+0.25 * 7.11 \approx$ Swedish kronor 2435 .

Table A3 Data used to calculate annual costs of losartan and candesartan treatment

\begin{tabular}{|c|c|c|c|c|c|c|}
\hline Drug & Dose & $\begin{array}{l}\text { Share } \\
\text { of patients }\end{array}$ & Price (SEK)/pill & Cost (SEK)/year & Manufacturer & Pack size \\
\hline Losartan & $50 \mathrm{mg}$ & 0.45 & 0.59 & 215.35 & KRKA Sverige & 98 \\
\hline Losartan & $100 \mathrm{mg}$ & 0.05 & 0.67 & 244.55 & STADAPharm & 98 \\
\hline Losartan/hydrochlorothiazide & $50 \mathrm{mg} / 12.5 \mathrm{mg}$ & 0.35 & 0.65 & 237.25 & KRKA Sverige & 98 \\
\hline Losartan/hydrochlorothiazide & 100 mg/25 mg & 0.15 & 0.77 & 281.05 & $\begin{array}{l}\text { Bluefish } \\
\text { pharmaceuticals }\end{array}$ & 98 \\
\hline Candesartan & $4 \mathrm{mg}$ & 0.15 & 5.9 & 2153.5 & AstraZeneca & $98 / 100$ \\
\hline Candesartan & $8 \mathrm{mg}$ & 0.35 & 6.38 & 2328.7 & AstraZeneca & 100 \\
\hline Candesartan & $16 \mathrm{mg}$ & 0.25 & 7.1 & 2591.5 & AstraZeneca & 100 \\
\hline Candesartan/hydrochlorothiazide & $16 \mathrm{mg} / 12.5 \mathrm{mg}$ & 0.25 & 7.11 & 2595.15 & AstraZeneca & 98 \\
\hline
\end{tabular}

Note: Cost/year is calculated as price/pill $* 365$.

Abbreviation: SEK, Swedish kronor.

\section{Publish your work in this journal}

ClinicoEconomics \& Outcomes Research is an international, peerreviewed open-access journal focusing on Health Technology Assessment, Pharmacoeconomics and Outcomes Research in the areas of diagnosis, medical devices, and clinical, surgical and pharmacological intervention. The economic impact of health policy and health systems organization also constitute important areas of coverage. The manuscript management system is completely online and includes a very quick and fair peer-review system, which is all easy to use. Visit http://www.dovepress.com/testimonials.php to read real quotes from published authors. 